\title{
Tourism development at World Heritage Site: The case of Loire Valley in France
}

Morice, Jean-René a

Liu, Yi-De ${ }^{b}$

Lin, Chi-Fan ${ }^{c}$

a Tourism School (ESTHUA), University of Angers, France.

b Graduate Institute of European Cultures and Tourism, National Taiwan

Normal University, Taiwan, Province of China. Corresponding Author: yideliu@ntnu.edu.tw

${ }^{c}$ Independent Scholar, Taiwan, Province of China.

\section{ARTICLE INFO \\ Article history: \\ Received 6 $6^{\text {th }}$ July 2020 \\ Accepted $27^{\text {th }}$ July 2020 \\ Published 28 th July 2020 \\ Keywords: \\ Cultural Landscape; \\ France; Loire Valley; \\ Tourism development; \\ World Heritage Site}

\section{A B S T RACT}

In 2000, UNESCO included a linear cultural landscape along a 200 kilometre stretch in the middle reaches of the Loire Valley, between Sully-sur-Loire and Chalonnes-sur-Loire. The management of this extensive cultural landscape is exemplary, innovative but also complicated. The aim of this article is to explore the challenges faced and strategies adopted by the Loire Valley as a World Heritage Site in the development of tourism. Quantitative and qualitative data were both used to enhance the depth and breadth of analysis. The work presented refers to three sources of data. The findings reveal that tourism development in the Loire Valley has some challengers, such as short stays of tourists, slow growth in tourist numbers, uneven visitor numbers between castles, and the blurred role of World Heritage status in destination image. However, three different aspects of strategies have been applied by the authorities to enhance tourism development, including governance and marketing, attraction development and activation, as well as synergies of local communities.

DOI: 10.1344/THJ.2020.2.6

\section{INTRODUCTION}

The World Heritage Convention signed in 1972 reflects the aim of United Nations Educational, Scientific and Cultural Organisation (UNESCO) to protect the world's cultural and natural heritage. The objective of the Convention is to encourage the identification, protection and preservation of cultural heritage properties which can be considered to be of 'outstanding universal value' due to their exceptional qualities, and as such are worthy of special protection from the dangers which increasingly threaten them (UNESCO, 2013, p.2). It is also a success story that has so far been considered for UNESCO in terms of exerting its wide influence (McKercher \& du Cros, 2002). As of 2019, a total of 1,121 World Heritage Sites (hereinafter referred to as WHS), including 869 cultural, 213 natural and 39 mixed properties, exist across 167 countries (UNESCO, 2018). Since the first 12 sites were listed as WHS in 1978, the number of listed WHS has been increasing, and the WHS list is expanding every year (Jimura, 2019). Countries are vying for WHS status, and the 
movement seems to be growing. Smith (2002) views WHS status as a double-edged sword, which can have both positive and negative effects. Santa-Cruz and López-Guzmán (2017) argue that "the recognition of a place as a WHS by UNESCO is fundamental to preserve its historical and artistic inheritance and, at the same time, to encourage visits to that area" (p.111). For instance, Canalea et al. (2019) confirmed the tourism-enhancing role of the WHS status. For the case of Italian provinces, it is found that being awarded with a WHS recognition, together with the province's wealth, environmental habits and the openness to external markets, may influence the attractiveness of destinations. However, Ribaudo and Figini (2017) demonstrated that at least for a mature destination like Italy, there is no statistical evidence that WHS listing is associated with accelerating tourism market growth. Tourism, on the other hand, began with the exploration of cultural and natural heritage. From the second half of the 17th century, the "Grand Tour" became a rite of passage for Europeans with the means and education (Trease, 1967). With the impact of globalisation and increased income and leisure time in the second half of the 20th century, the scale of heritage tourism has expanded from a small stream to a great river (Ryan \& Silvanto, 2009). Morice (2009) believes that heritage and tourism are co-production. Although ordinary people judge by common sense that heritage is an incentive to attract tourists; in fact, the phenomenon of tourism has also promoted the production of heritage. Tourism practices can change the natures of heritage sites by giving them some memorable and aesthetic values. For tourism, being named as WHS suggests unique and globally-recognised attractions and opportunities. However, at the same time, it imposes multiple layers of restrictions on development and operations (Buckley, 2018). In addition, Gravari-Barbas et al. (2015) and others also revealed the weak existence of "tourism" in the WHS Convention. "Tourist" is the only word related to "tourism", and it appears only once in the WHS Convention (Article 11.4). However, in recent years, UNESCO, International Council on Monuments and Sites (ICOMOS), academics and practitioners have become more aware of the scale of WHS tourism (Jimura, 2019). Different scholars, Gravari-Barbas et al. (2015), Meskell (2013) and Pedersen et al. (2007) have also studied tourism management in WHS from many different perspectives.

In 2000, UNESCO included a linear cultural landscape along a 200 kilometre stretch in the middle reaches of the Loire Valley, between Sully-sur-Loire and Chalonnes-sur-Loire (see Figure 1). The jury stated that the Loire Valley is: "an outstanding cultural landscape of great beauty, containing historic towns and villages, great architectural monuments (the castles), and cultivated lands formed by many centuries of interaction between their population and the physical environment, primarily the river Loire itself" (UNESCO, 2020). In the context of the World Heritage Convention, cultural landscape represents the combined works of nature and people. Cultural landscape reflects not only the stories which shaped people in the past, but also the stories of people today. To determine cultural landscape, it is necessary to consider nature and cultural elements as a whole (Sirisrisak \& Akagawa, 2007). In fact, the World Heritage Committee held a lengthy debate over the Loire Valley. It is generally believed that the Loire Valley has outstanding universal value and is worthy of being included in the cultural landscape of the World Heritage List according to cultural standards.

The management of this complex and extensive cultural venue is exemplary, innovative and appropriate. However, some representatives expressed concern about nuclear power 
plants located within the proposed site. As a result, the World Heritage Committee has postponed consideration of this matter. This discussion illustrates the complexity of cultural landscape protection, especially for living cultural landscapes (Rössler, 2000). For example, McKercher \& du Cros (2002) point out that cultural landscapes have tested the effectiveness of current cultural heritage management procedures. Cultural landscape is an environmental background that has both cultural and natural values. Because of their immaterial nature, and more importantly, because they often cross state and provincial borders, they pose special challenges to management. Linear landscapes and heritage routes are considered as special types of cultural landscape and they have their own management requirements (Rössler, 1994). In addition, this kind of territory has been used by the tourism sector, and it is more difficult to manage them carefully and effectively (McKercher \& du Cros, 2002).

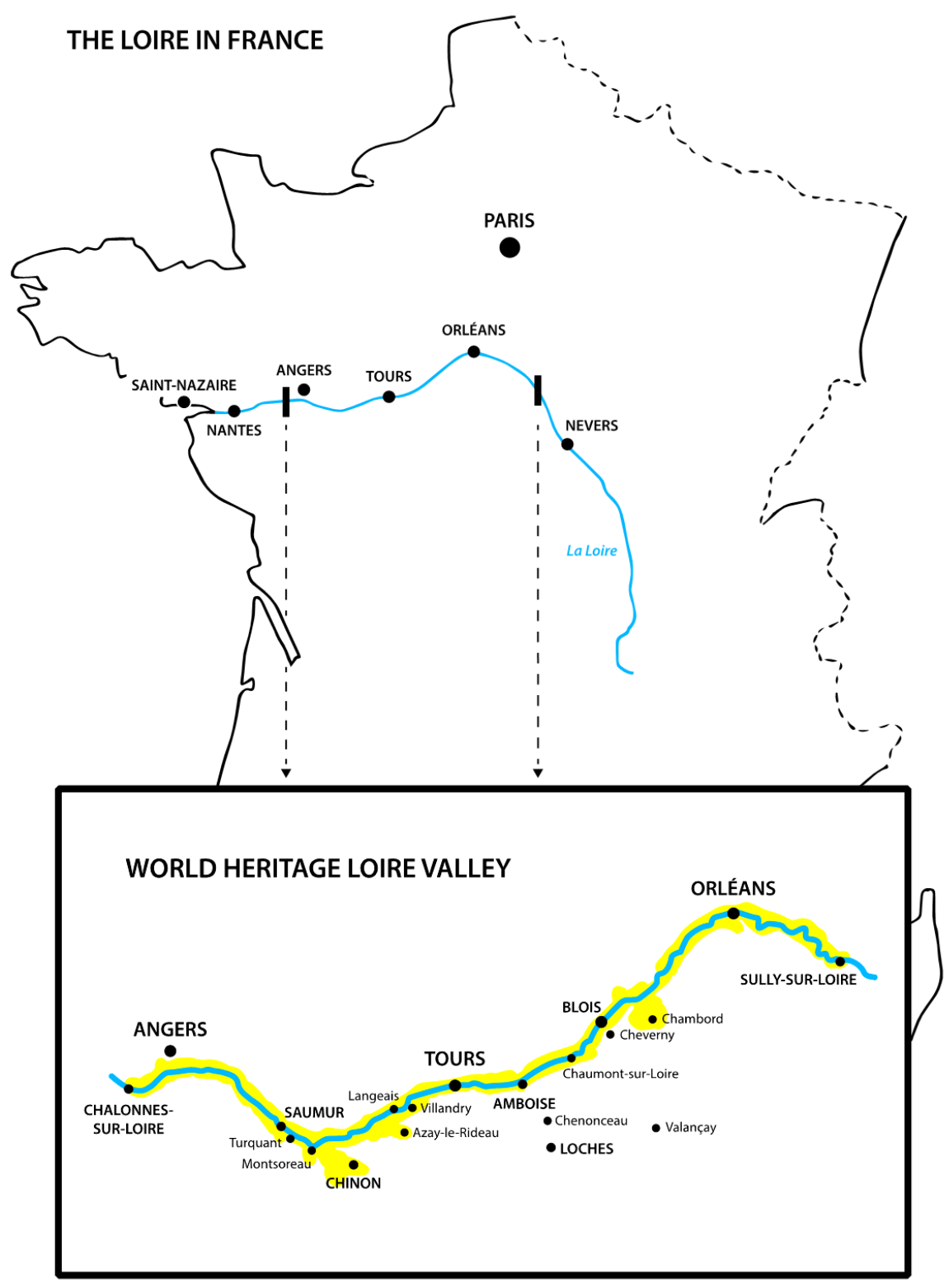

Figure 1. Map of the Loire river and the part classed as UNESCO WHS. Source: Drawn by the author 
The Loire Valley may be regarded as a tourist territory and can be divided into two regions. One is the upstream region, which extends from Tours to Chambord and even as far as Orleans; the other is the downstream region, which extends to Saumur (Morice \& Violier, 2009). The heritage sites in the Loire Valley are clearly related to the "Historical Monument" system created in France in 1840. A total of 934 ancient and medieval public buildings were listed as the first historical sites, including 42 in the Loire Valley. The Loire Valley's heritage is internationally recognised, and Chambord Castle was named as a UNESCO WHS in 1981. In 2002, the "Loire Valley Project" (Mission Val de Loire) was established to govern the WHS territory. It is an interregional union, two-thirds funded by the Central Region and the remaining one-thirds by the Pays de la Loire Region (Morice \& Violier, 2009). The aim of this article is to explore the challenges faced and strategies adopted by the Loire Valley as a WHS cultural landscape in the development of tourism. It is done by investigating the following three aspects: governance and marketing, attraction development and activation, as well as community and tourism development.

\section{RESEARCH METHODS}

In terms of research methods, quantitative and qualitative data were both used to enhance the depth and breadth of analysis. The work presented refers to the following three sources of data. The first source is large-scale survey carried out in 2010 by the University of Angers, placed under the scientific responsibility of the first author of this paper, and conducted in partnership with the study firm Public \& Culture, on behalf of the Mission Val de Loire World Heritage. The survey aims to explore the profiles and patterns of visitors to the major sites of the Loire Valley: 19 visitor sites surveyed in total (Morice \& Chevrel, 2010). This survey offers a valuable statistical analysis of the understanding of visitor behaviour in the Loire Valley. The content of the study has so far remained somewhat confidential, only brought to the attention of the managers of the sites surveyed and of the Loire Valley Mission - World Heritage. We propose here to offer for the first time a dissemination and an interpretation of the results. We are talking about going back to the main highlights of the study. The survey was carried out during the summer period, July and August 2010, questioning individual visitors aged 18 and over at the major sites in the Loire Valley. The method chosen was face-to-face, with questionnaires being administered by interviewers speaking at least 3 languages.

The questionnaire, translated into 5 languages and comprising 47 questions, including 15 open questions, was given to visitors at the end of their visit on the basis of one questionnaire per visiting cell. Around 200 to 600 questionnaires per site were made available proportional to the number of visitors to the site resulting in a total of 6,100 questionnaires being collected and processed. The result is a rich statistical analysis offering a heritage and tourist interpretation of the Loire Valley that has never been seen before. All the data collected was analysed using several methods making it possible to account for either a global behaviour of visits on the scale of the Loire Valley, or a behaviour specific to a segment of visitors, or a diversity of behaviours linked to a subset of sites. However, this single-period survey did not represent tourist behaviour year-round. The key descriptive statistics are shown in Table 1. 44\% of tourists in Loire Valley is spent 4-7 days there, $26 \%$ stayed for more than 8 days, and 30\% less than 3 days. $66 \%$ of tourists visiting the important attractions in Loire Valley were domestic French tourists, and the proportion of 
first-time visitors was low (only 15\%). In contrast, the proportion of frequent visitors (40\%) and occasional visitors (45\%) was relatively high.

Qualitative interviews are the second data source. To investigate the issue of local community and tourism development, field studies were conducted in two towns along the Loire Valley - Turquant and Montsoreau (see Figure 1 for the locations). The main purpose was to explore the advantages and disadvantages of tourism development from a community perspective. The mayors of both Turquant and Montsoreau were interviewed twice by the first author in 2009 and 2019. The results were complemented by subsequently interviewing the director of the Loire Anjou Touraine Regional Natural Park, the director of the Saumur tourist office, and key public and private actors and organisations involved in heritage and tourism in the two towns. As a third source, the 2010 visitor survey was complemented by the use of more recent statistics from the national tourism survey, published every year by Direction générale des entreprises (DGE, 2019).

Table 12010 Loire Valley tourist survey: descriptive statistics

\begin{tabular}{lrlr}
\hline \multicolumn{1}{l}{ Age } & & Nationality & \\
\cline { 1 - 1 } Less than 30 yrs & $12 \%$ & France & $66 \%$ \\
$40-39$ yrs & $20 \%$ & UK & $6 \%$ \\
$50-59$ yrs & $26 \%$ & Belgium & $5 \%$ \\
60 yrs+ & $22 \%$ & Italy & $4 \%$ \\
& $20 \%$ & Germany & $4 \%$ \\
Duration of stay & & Netherlands & $3 \%$ \\
Less than 2 days & & Spain & $3 \%$ \\
$2-3$ days & $8 \%$ & Others & $9 \%$ \\
$4-7$ days & $22 \%$ & & \\
8 days+ & $44 \%$ & Frequency of visit & $15 \%$ \\
\cline { 3 - 4 } & $26 \%$ & First time & $45 \%$ \\
& & Occasional visit & $40 \%$ \\
\hline
\end{tabular}

Source : Morice, J. R. \& Chevrel, R. (2010). Étude des comportements des visiteurs des grands sites du Val de Loire. Survey report commissioned by Mission Val de Loire. France: University of Angers and Public \& Culture.

\section{GOVERNANCE AND MARKETING}

In terms of governance, WHS does not include a separate agency for governance, development, and supervision (Bianchi \& Boniface, 2002; Jimura, 2019). Governance for many natural WHS is often found to be part of a wider protected area and national park system, and therefore falls under the jurisdiction of public sector agencies and is governed by their respective management policies (Leask \& Fyall, 2006). Violier (2003) believes that institutions transcending administrative boundaries are more compatible with territories beyond administrative boundaries and can ensure the consistency of tourism space. However, institutions across administrative boundaries are very rare. Basically, there are two forms of strategic institutions which transcend administrative boundaries in the Loire Valley. The first is based on the alliance and cooperation of the original subregional institutions, and the other is the establishment of an innovative organisation under the new territorial framework. Bringing institutional participants together, the first model is a 
cooperation between the Maine-et-Loire and Indre-et-Loire departmental tourism committees. The more familiar names are the former provincial titles of Anjou and Touraine. In addition, a strategy which regards the Loire Valley as an entire tourism territory was adopted, with the development of an Action Plan for Maine-et-Loire. The organisation "Castles of the Loire, Valley of the Kings" is an example of the second model. The organisation unifies those marked as "Historic Monuments" or "Extraordinary Gardens" in the Loire Valley (the two regions- Center Loire Valley and Pays de Loire) and are open to the public. To date, it has included more than 80 attractions and printed more than 6 million brochures. The "Great Sites of the Loire Valley" is the other inter-regional organisation - a network of Loire Valley heritage sites and tourism agencies. Several major sites signed the "Charter of Excellence" in 2008 and developed a multi-year action plan. The official website was launched in 2009, resulting in a peak in visitor numbers in 2017 (Morice \& Violier, 2009).

Moreover, The WHS title has become a highly valued brand used by countries and cities to market themselves as tourist attractions. People often describe WHS attractions as magnets for attracting tourists (Hall \& Piggin, 2003; Ryan \& Silvanto, 2009; Shackley, 1998). Having WHS status can enhance the visibility and image of the site, and the quality and characteristics of WHS certified brands play a key role in promotion and marketing (Jimura, 2016; Leask \& Fyall, 2006; Ryan \& Silvanto, 2009; 2014; Smith, 2002). In fact, the selection criteria of WHS guarantee the superiority of attractions, and WHS represents a commitment to value and differentiation. The importance of WHS as a destination brand can be evidenced by the sharp increase in the number of attractions regarding WHS status submitted by different countries in recent years (Ryan \& Silvanto, 2014). Although there is a lot of anecdotal information about the role and importance of WHS titles in attracting tourists (e.g. Carter et al., 2000; Hall \& McArthur, 1998; Pocock, 1997; Shackley, 1998; Thorsell \& Sigaty, 2001), Hall and Piggin (2002) argue that its impact may be exaggerated. Given the diversity of locations, such as their size, nature, and location, it is difficult to generalise the overall impact of WHS titles on attracting tourists (Ryan \& Silvanto, 2009). For most WHS tourist destinations, it is a challenge to establish and adopt a consistent approach to tourist destination marketing and build a clear vision for their future as WHS and tourist destinations (Jimura, 2019). This challenge stems from the fact that WHS often has many stakeholders (e.g. UNESCO, national governments, tourism sectors etc.) (Ryan \& Silvanto, 2009) and must cater for the needs of groups with different motivations, often including passive heritage visitors (similar to mass tourists) and serious heritage visitors (similar to special interest tourists) (Leask \& Fyall, 2006).

According to the survey conducted by Morice \& Chevrel (2010), historical heritage, natural landscapes and food/ wine are the three most important perceived images of the Loire Valley (see Table 2). As for the motivation of tourists, visiting castles is an important factor of tourist behaviour in the territory. 63\% of tourists mainly visited castles and heritage sites, whereas $23 \%$ were driven by the Loire's reputation. The natural environment and food/ wine accounted for $23 \%$ and $22 \%$ respectively. In addition, one third of domestic tourists visiting Loire booked a tour taking in several castles. For international tourists, this proportion increased to $45 \%$. The top three perceived images of the Loire Valley are: historical monuments /castles (80\%), Loire river, natural sites (57\%), wine and gastronomy (41\%). Visitors' activities were also closely related to their motivations and 
perceived images, namely visits to historical monuments and towns (45\%), food and wine tasting (28\%), nature-related walking or hiking (26\%), and relaxation and rest (23\%). Generally speaking, the visits combine both cultural tourism and leisure activities. The survey results reflect the claims of McKercher et al. (2002) that, although many serious heritage tourists may explore a cultural heritage in depth, other tourists will seek to visit multiple WHS attractions as part of their overall vacation plan. Although heritage tourists are different from traditional tourists, they are also heterogeneous groups with a wide range of interests (Ryan \& Silvanto, 2014).

Table 22010 Loire Valley tourist survey: motivations, images and activities

\begin{tabular}{|c|c|c|c|}
\hline Motivations & \multirow[b]{2}{*}{$63 \%$} & Activities & \multirow[b]{2}{*}{$45 \%$} \\
\hline Heritage \& castles & & Visiting cities / villages & \\
\hline Reputation of the region & $23 \%$ & Wine tasting & $28 \%$ \\
\hline Nature \& environment & $22 \%$ & Walking / hiking & $26 \%$ \\
\hline Wine \& gastronomy & $15 \%$ & Relaxation / rest & $23 \%$ \\
\hline Visiting relatives or friends & $12 \%$ & Visiting parks / gardens & $17 \%$ \\
\hline Calm / tranquillity & $9 \%$ & Cultural activities & $15 \%$ \\
\hline Convenience / accessibility & $5 \%$ & Bike rides & $14 \%$ \\
\hline Professional reasons & $2 \%$ & Water activities & $11 \%$ \\
\hline Promotion, special offer etc. & $1 \%$ & Visiting leisure sites & $8 \%$ \\
\hline \multirow[t]{2}{*}{ Others } & $16 \%$ & Sporting activities & $7 \%$ \\
\hline & & Others & $11 \%$ \\
\hline \multicolumn{4}{|l|}{ Images } \\
\hline Historical monuments /castles & $80 \%$ & Gardens & $17 \%$ \\
\hline Loire river, natural sites & $57 \%$ & French style / way of life & $10 \%$ \\
\hline Wine \& gastronomy & $41 \%$ & As a UNESCO WHS & $9 \%$ \\
\hline $\begin{array}{l}\text { Reputation within Franch } \\
\text { history }\end{array}$ & $18 \%$ & Others & $3 \%$ \\
\hline
\end{tabular}

Source : Morice, J. R. \& Chevrel, R. (2010). Étude des comportements des visiteurs des grands sites du Val de Loire. Survey report commissioned by Mission Val de Loire. France: University of Angers and Public \& Culture.

In terms of tourism marketing and branding, the Loire Valley faces the following four dilemmas. First, the behaviour of tourists in the Loire Valley is characterised by short-stays, and most tourists undertake a day trip to and from Paris (Duhamel \& Knafou, 2007). Secondly, from 1998 to 2004, the rankings of the top nine castles with the highest number of visitors were basically the same, except that the number of visitors dropped from 2.2 million to 1.9 million. However, the total number of tourists in France at the same time increased from 28 million to 76 million, which shows that the number of tourists in the Loire Valley was below the national average (Morice \& Violier, 2009). Also, according to the 2018 National Tourism Survey (see Table 3), the Ile-de-France region alone accounts for almost a third of national jobs in the tourist accommodation sector and attracts a third of overnight stays by international tourists. However, if we compare the two regions where the Loire Valley is located - Centre-Val de Loire and Pays de la Loire - with 11 other regions in France, whether for "overnight stays by international tourists" or "paid staff in the tourist accommodation sector", the Loire Valley only accounts for $4 \%-6 \%$ of the national total and 
ranks between $10^{\text {th }}-13^{\text {th }}$. In terms of "overnight stays by domestic tourists", the Pays de la Loire performs slightly better, accounting for $7 \%$ nationwide (ranked $6^{\text {th }}$ ); however, CentreVal de Loire accounts for only $3 \%$ (ranked $12^{\text {th }}$ ). These all show the limitations of the Loire Valley as WHS in terms of tourism development and the economic spin-offs generated by tourism.

Table 32018 Tourism statistics and ranking of 13 Regions in France

\begin{tabular}{|c|c|c|c|c|c|c|}
\hline \multirow[t]{2}{*}{ Region } & \multicolumn{2}{|c|}{$\begin{array}{l}\text { Overnight stays by } \\
\text { international tourists }\end{array}$} & \multicolumn{2}{|c|}{$\begin{array}{l}\text { Overnight stays by } \\
\text { domestic tourists }\end{array}$} & \multicolumn{2}{|c|}{$\begin{array}{l}\text { Paid staff in the tourist } \\
\text { accommodation sector }\end{array}$} \\
\hline & $\%$ & Ranking & $\%$ & Ranking & $\%$ & Ranking \\
\hline Auvergne-Rhône-Alpes & $11 \%$ & $3^{\text {rd }}$ & $13 \%$ & 3 rd & $16 \%$ & $2^{\text {nd }}$ \\
\hline Bourgogne-Franche-Comté & $4 \%$ & $6^{\text {th }}$ & $4 \%$ & $11^{\text {th }}$ & $3 \%$ & $11^{\text {th }}$ \\
\hline Bretagne & $4 \%$ & $7^{\text {th }}$ & $8 \%$ & $5^{\text {th }}$ & $4 \%$ & $7^{\text {th }}$ \\
\hline Centre-Val de Loire & $2 \%$ & $10^{\text {th }}$ & $3 \%$ & $12^{\text {th }}$ & $3 \%$ & $12^{\text {th }}$ \\
\hline Corse & $2 \%$ & $11^{\text {th }}$ & $2 \%$ & $13^{\text {th }}$ & $1 \%$ & $14^{\text {th }}$ \\
\hline Grand Est & $4 \%$ & $8^{\text {th }}$ & $5 \%$ & $8^{\text {th }}$ & $7 \%$ & $6^{\text {th }}$ \\
\hline Hauts de France & $2 \%$ & $12^{\text {th }}$ & $4 \%$ & $10^{\text {th }}$ & $4 \%$ & $9^{\text {th }}$ \\
\hline Ile de France & $27 \%$ & $1^{\text {st }}$ & $5 \%$ & $7^{\text {th }}$ & $26 \%$ & $1^{\text {st }}$ \\
\hline Normandie & $4 \%$ & $9^{\text {th }}$ & $5 \%$ & $9^{\text {th }}$ & $4 \%$ & $8^{\text {th }}$ \\
\hline Nouvelle Aquitaine & $9 \%$ & $5^{\text {th }}$ & $15 \%$ & $1^{\text {st }}$ & $8 \%$ & $4^{\text {th }}$ \\
\hline Occitanie & $11 \%$ & $4^{\text {th }}$ & $15 \%$ & $2^{\text {nd }}$ & $7 \%$ & $5^{\text {th }}$ \\
\hline Pays de la Loire & $2 \%$ & $13^{\text {th }}$ & $7 \%$ & $6^{\text {th }}$ & $3 \%$ & $10^{\text {th }}$ \\
\hline Provence-Cote d'Azur & $16 \%$ & $2^{\mathrm{rd}}$ & $12 \%$ & $4^{\text {th }}$ & $12 \%$ & $3^{\text {rd }}$ \\
\hline Others & $2 \%$ & $14^{\text {th }}$ & $1 \%$ & $14^{\text {th }}$ & $2 \%$ & $13^{\text {th }}$ \\
\hline
\end{tabular}

Source : DGE (2019). Mémento du Tourisme. Edition 2018. Paris: Direction générale des entreprises (DGE).

Third, although the castles play an important role in this territory, there is an unequal relationship between them. The territory is only partially used by tourists (Morice, 2019). Both to the east and west of the city of Tours, there are two famous sightseeing complexes of castles open to tourists, following the course of the Loire Valley: one upstream towards Chambord, and the other downstream towards Saumur. Aside from these two tourist concentration areas, visitors are not non-existent but relatively scarce. The survey (Morice \& Chevrel, 2010) tends to confirm the reality that tourists concentrate around a few wellknown castles. Although the Loire Valley has a large number of sightseeing castles, tourists generally prioritise seven of them - Chambord, Chenonceau, Amboise, Cheverny, Villandry, Blois and Azay le Rideau (see Figure 2). Tourist numbers in the Loire Valley are largely the result of visits to these castles, especially Chambord and Chenonceau, which are regarded as essential during a visit to the territory, whether starting or continuing one's discovery of the Loire Valley (see Table 4). However, many other sites in the Loire Valley are outside the reach of international tourists. Fourth, $66 \%$ of tourists are aware that the Loire Valley has been listed as a UNESCO WHS and "driven by the Loire's reputation" ranked second among visitors' motivations, indicating that this motivation has an indirect relationship with the UNESCO inscription. However, the status of WHS plays only a minor role in the territory's image because the concept of a cultural landscape is abstract and complex, and it is difficult to obtain an accurate image of a destination. 


\section{VISITOR NUMBERS}

OF THE LOIRE CASTLES IN 2019
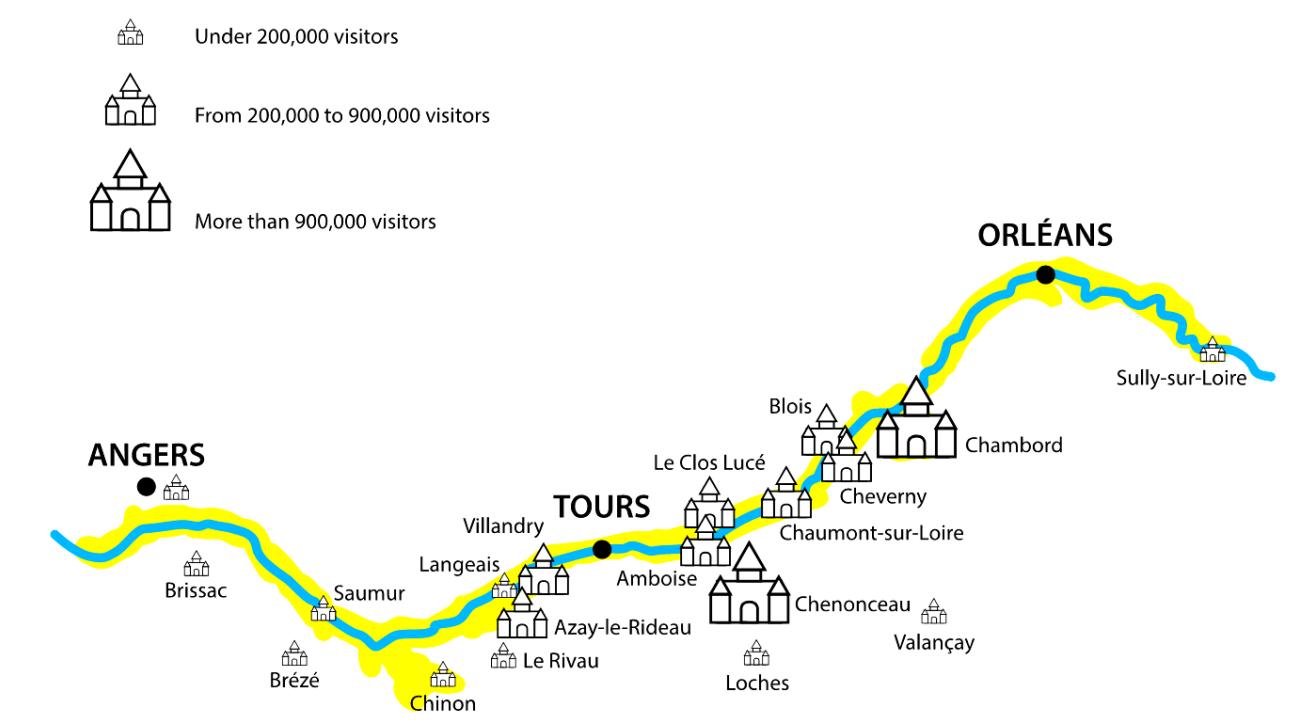

Figure 2 Distribution of castles' visitor numbers in the Loire Valley, 2019. Source: Drawn by the author (2020)

Table 4 Ranking of castles' visitor numbers in the Loire Valley, 2010

\begin{tabular}{lcccc}
\hline \multirow{2}{*}{ Castle } & \multicolumn{2}{c}{ Previous site visited } & \multicolumn{2}{c}{ Next site visited } \\
\cline { 2 - 5 } & $\%$ & Ranking & $\%$ & Ranking \\
\hline Chenonceau & $23.2 \%$ & $1^{\text {st }}$ & $12.4 \%$ & $1^{\text {st }}$ \\
Chambord & $22.0 \%$ & $2^{\text {nd }}$ & $11.0 \%$ & $2^{\text {nd }}$ \\
Amboise & $12.4 \%$ & $3^{\text {rd }}$ & $9.5 \%$ & $3^{\text {rd }}$ \\
Cheverny & $12.3 \%$ & $4^{\text {th }}$ & $8.0 \%$ & $4^{\text {th }}$ \\
Villandry & $10.0 \%$ & $5^{\text {th }}$ & $6.9 \%$ & $6^{\text {th }}$ \\
Blois & $9.1 \%$ & $6^{\text {th }}$ & $7.0 \%$ & $5^{\text {th }}$ \\
Azay le Rideau & $9.0 \%$ & $7^{\text {th }}$ & $6.1 \%$ & $7^{\text {th }}$ \\
\hline
\end{tabular}

Source : Morice, J. R. \& Chevrel, R. (2010). Étude des comportements des visiteurs des grands sites du Val de Loire. Survey report commissioned by Mission Val de Loire. France: University of Angers and Public \& Culture.

In order to use WHS status as an effective brand for destination marketing, all major stakeholders in the destination need to work together and should have a clear vision of the future of WHS or destinations with WHS. Having such a vision requires identifying some desired future pictures and clarifying what they intend to achieve (Evans, 2015). Aiming to strengthen the brand image of the Loire Valley, a new destination brand logo was proposed in 2012 and recognized by the country in 2014. It is named "Loire Valley" (Val de Loire) and includes the two regions - Centre Loire Valley and Pays de Loire. The symbol of this new 
destination brand not only reflects the castles, but also hopes to highlight the valuable assets of the Loire Valley, such as natural landscapes, food and wine. The Loire Valley also has an intention to become a national benchmark for destination branding.

\section{ATTRACTION DEVELOPMENT AND ACTIVATION}

Scholars such as McKercher \& du Cros (2002), Leask \& Fyall (2006), and Shackley (1998) believe that, although having WHS status may lead to the success of tourism development, the development of cultural and tourist attractions, the activation of assets and accessibility etc., are all key success factors over and above destination governance and marketing. First of all, McKercher \& du Cros (2002) offer the following strategies for developing cultural heritage assets into cultural tourism attractions, including: (1) Building a primary attraction (new or through adaptive re-use), enhance existing but undeveloped heritage assets or specifically establish a cultural or heritage theme park to build first-level cultural and tourist attractions. (2) Packaging and bundling, combining products and experiences of similar themes, and then promoting the collective consumption of these products to tourists in order to encourage them to comprehensively consume the whole destination, rather than just 2-3 assets. (3) Clustering through the creation of tourism precincts: an extreme combination. Clustering can result in product clusters which are more convenient for tourists to use. More tourists will also enhance business opportunities for auxiliary attractions and suppliers. (4) Developing linear touring routes or heritage networks: combining different attractions into a themed tourism route to create an attractive firstlevel one and enhance the attraction of individual spots (Stocks, 1996). (5) Events: festivals or events are able to concentrate a large number of activities in a compressed time frame, thereby forming a product cluster for tourism consumption which can be regarded as temporary first-level attractions. On the other hand, McKercher \& du Cros (2002) also point out that cultural tourists represent high-level markets. They are well-educated, have travel experience, and are mature and experienced tourists seeking unique and interesting experiences. They then put forward a series of elements to be a successful cultural tourism attraction, including telling a story, making the asset come alive, making the experience participatory, focusing on quality and making it relevant to the tourist.

The Loire Valley tourist territory is characterised by significant asymmetry, especially with regard to the visitor numbers to the castles. In addition, Morice and Violier (2009) point out that although the tourism institutions of the Loire Valley emphasise that "a majestic river can definitely be explored" (p.93), it is in fact difficult for tourists to get close to the Loire River and river-related activities are quite limited. Also, the Loire Valley is not a major destination for water-based activities. In general, local conditions make the Loire Valley less accessible. The two roads along the river bank are narrow, tortuous, and unsafe. For motorists, parking spaces are scare and pedestrians don't have much space to walk. In addition, there are few spots, restaurants or accommodations with views of the Loire Valley. As far as cultural and tourist attraction development strategies are concerned, the most successful case in the Loire Valley is the development of a linear bike lane - "Loire by Bike" (Loire à Vélo). According to Morice (2015), the 200-km long WHS did not attract the attention of the tourism industry for a long time. In order to develop the Loire Valley into a recognised tourist destination, the six provinces of the Centre-Loire Valley and Pays de la Loire, including Cher, Loiret, Loir-et-Cher, Indre-et-Loire, Maine-et-Loire and Loire Atlantic, 
and six metropolitan areas, including Orleans, Blois, Tours, Saumur, Angers and Nantes, started this large-scale bike lane project, with the aim of updating radically regional tourism services. Loire by Bike includes the necessary amenities along the road, especially signage and those services expected by tourists. To a certain extent, it has opened up the river valley to tourists, allowing them to get closer to the water and provides more experiences than can be acquired by motor-tourism (see Figure 3). This concept originated in 1995, but a cycling route with perfect road signs and rider-protection was launched in 2010. Loire by Bike provides visitors with the opportunity for in-depth experiences, and to wander, rest, and recover in the tranquil scenery. It is a tourist product, a destination, and also, a crossregional network practice.

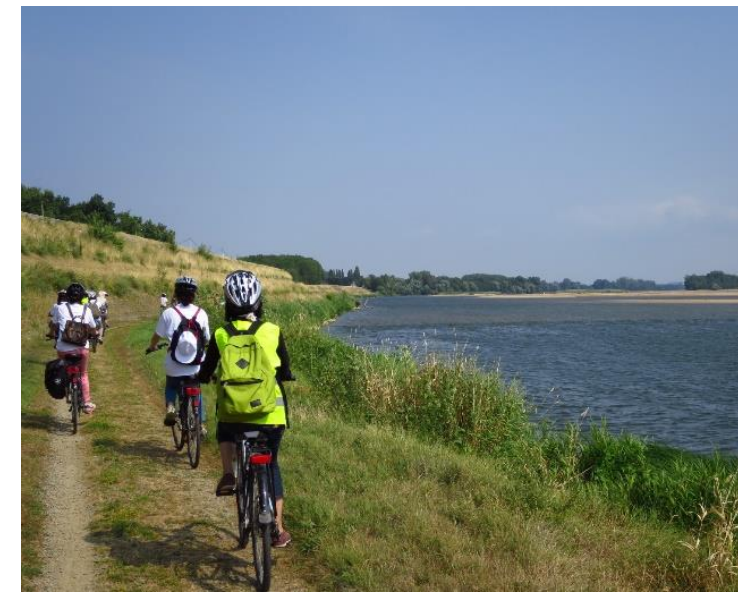

Figure 3. Loire by Bike allows visitors to get closer to the water and provides more experiences. Source: Author's own photo (2019)

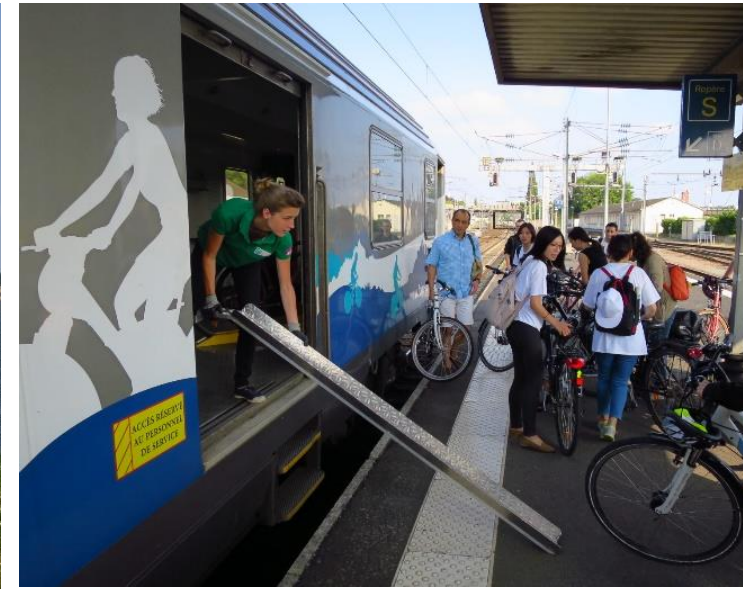

Figure 4. Loire by Bike provides convenient bike rental and transport services. Source: Author's own photo (2019)

The Loire by Bike project provides more than 300 stops along the bank of the Loire for cyclists to take a break. There are over 500 service providers included in the Loire by Bike brand, including accommodation, restaurants, bike rental and repair companies, specialised companies involved in baggage transfer, and 16 connecting railway stations (see Figure 4). The originally separate areas can now interact due to Loire by Bike, and are becoming a structural element of the Loire Valley for building a single tourist territory and confirming the continuity of the entire valley. Before that, it was basically characterised by the images of castles. Loire by Bike has successfully shaped the rich diversity and continuity of the Loire Valley. Inspired by the experience of Loire by Bike, other organisations are working hard to provide tourism offers based on the Loire Valley as a whole, especially the Great Heritage Sites network of the Loire Valley, combining "Castles of the Loire" and the attractions of "Valley of the King" to enhance the Loire Valley's international popularity. Loire by Bike has also shaped a new tourism portal which can continue to develop the attractiveness of the destination. According to the survey, $36 \%$ of the 800,000 tourists who visit the Loire Valley by bike are foreigners (Dutch, German, Belgian, British, American, Canadian, Australian, Japanese, etc.) (Morice, 2015). Loire by Bike was named as the best tourist attraction in 2012 by the British Guild of Travel Writers, and praised it as the longest and most sustainable eco-tourism project of the past ten years. Loire by Bike saw 802,000 bike tourists in 2012, and it was estimated to have had an economic impact of $17 \mathrm{~m}$ Euros, thus 
making it the most popular cycling destination in France today. In addition, in 2014, the new brand image of Val de Loire was created, meaning that in addition to the castles and the wineries, the Loire Valley has now another attraction- Loire by Bike (Morice, 2015).

Second, in response to the declining trend of castle visits, managers have implemented many product diversification strategies to ensure the competitiveness of heritage sites. For example, the castles of Chambord and Clos Lucé hold events to promote heritage sites to specific audiences (see Figures 5 and 6). These activation approaches appear to be more widely implemented in private institutions, whilst public actors tend to be more cautious. The success of tourism development depends on the ability of destinations to self-renew. The purpose of most tourists is the pursuit of rest and relaxation, and the stability and consistency of service is therefore of paramount importance. However, for tourists in the Loire Valley, in-depth exploration may be the main purpose (Amélie-Emmanuelle, 2007), so the proliferation and growth of the tourist area depends on whether the attractions can renew their supply, either by reducing ticket prices to promote local participation, or by implementing activation strategies to encourage tourists to revisit the site. The opportunity for direct contact with the Loire river can be found in the visitor centre - Loire Odyssée, which can be regarded as a showcase of the Loire Valley. In addition to information on the history, geography, and sightseeing in the Loire Valley, a guided river cruise service is currently available to the public (see Figures 7 and 8) (Morice \& Violier, 2009).

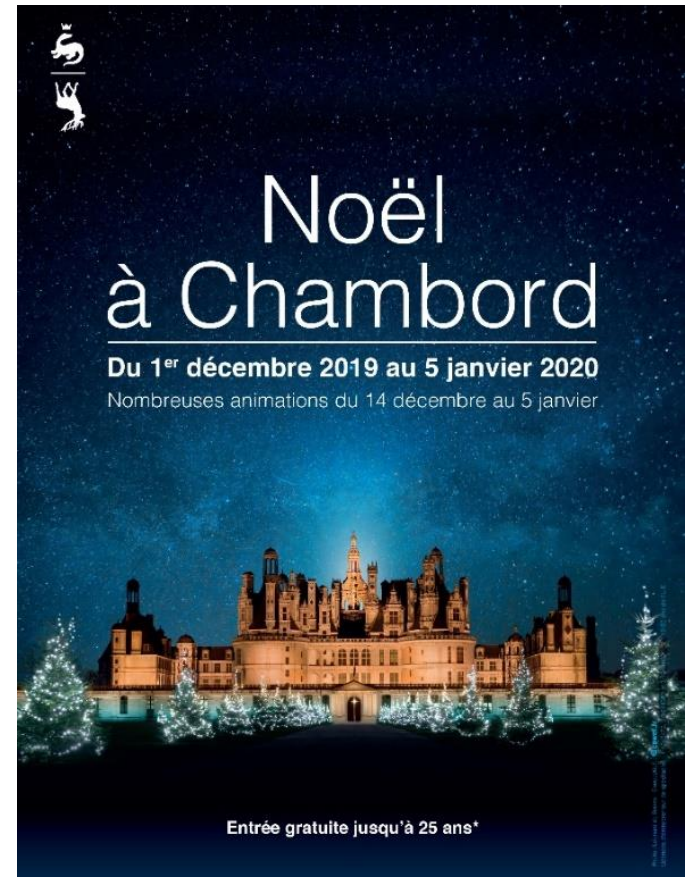

Figure 5. Chambord hosted Christmas event to animate the castle. Source: Provided and authorised by Chambord castle (2019)

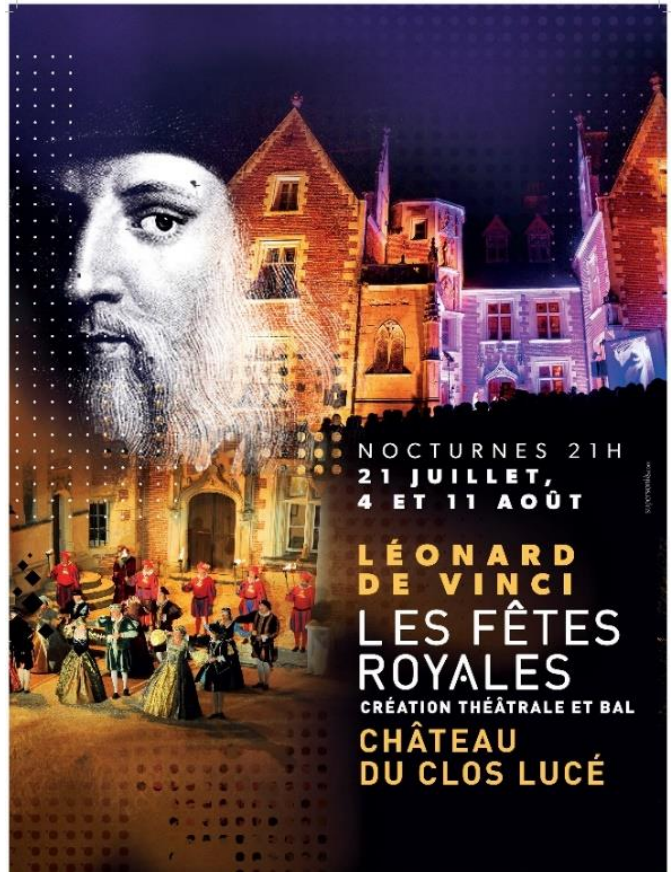

Figure 6. Clos Lucé was the residence of Leonardo da Vinci. The castle hosted event to commemorate the 500th anniversary of his death. Source: Provided and authorised by Clos Lucé (2019) 


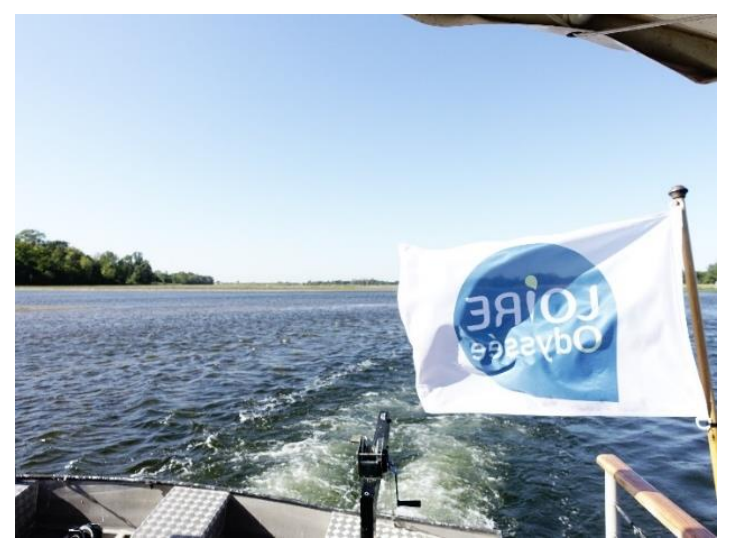

Figure 7. Guided Loire river-cruise service offered by Loire Odyssée. Source: Author's own photo (2019)

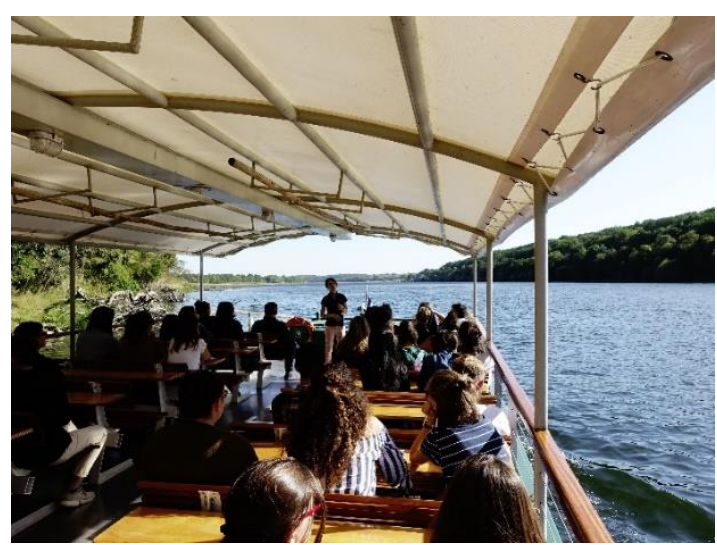

Figure 8. Loire river cruise offers visitors an opportunity to get close to the Loire river. Source: Author's own photo (2019)

Finally, according to the results of the 2010 visitor survey (see Table 2), the "typical" visitors to the Loire Valley's attractions are those who are familiar with heritage and cultural activities, staying in the country for 6 days, and visiting 4 castles. Visiting the castle is the main motivation for travelling, but discovering natural attractions and tasting food and wine are also crucial for visitors. The survey confirms that tourists in the Loire Valley are mostly well-educated cultural tourists who are familiar with heritage and therefore relatively demanding of services and attractions. The Loire Valley proves the diversity of its assets, including heritage, nature, wine and cuisine; and is a territory worth visiting again ( $53 \%$ of visitors visit return). In addition, most tourists have a good understanding of local culture. In order to satisfy those demanding visitors and increase revisiting rates, the Loire Valley must make continuous improvements. As suggested by Leask \& Fyall (2006), the development of some remotely located attractions, if some basic requirements are not met, are difficult to market the attractions to visitors, resulting in a limited number of tourists. These tangible elements, combined with the intangible experience provided, constitute a comprehensive product of the attraction.

\section{COMMUNITY AND TOURISM DEVELOPMENT}

Local residents are an important part of the WHS and they play a role in supporting heritage spaces at local, regional and national scales (Robinson et al., 1994). Leask \& Fyall (2006) argue that there must be a link between the universal value of WHS and local value in order to have a sustainable future. Local perceptions of tourism are particularly important for tourism development. Andereck and Vogt (2000) believe that the locals ultimately decide what changes caused by the tourism industry are acceptable to them. In tourist destinations, local people's views on the various changes are more important for tourism development than the actual changes resulting from tourism. This also applies to WHS, where local residents may be eager to show visitors their WHS or use it as a tourism resource, with a view to gaining economic benefits. In many places, tourism is an important tool for community development, especially for local communities situated in rural or remote areas (Garrod et al., 2006). For instance, Rasoolimanesh et al. (2017) revealed significant differences between the effects of economic gain and community involvement on residents' perceptions in rural and urban contexts. In some areas, tourism is the only industry allowing economic development. On the other hand, tourism can be an alternative to those industries 
in decline (Jimura, 2011). The positive attitude of locals towards the development of tourism is thus crucial to the development of communities through tourism. As Kuvan and Akan (2005) point out, many researchers acknowledge the importance of local community support for the successful development of tourism. Similarly, residents may prefer to protect their privacy and lifestyle, especially during peak tourist seasons. But in practice, local residents and community groups are often largely excluded from the consultation and management process. In many cases, the ability of local people and local infrastructure to effectively respond to tourist demand is also not considered (Leask \& Fyall, 2006). Even if locals initially have high expectations for tourism, their support may diminish over time (Johnson et al., 1994).

Morice and Violier (2009) point out the contradiction between the openness and closure of the Loire Valley by comparing two towns along the Loire Valley - Turquant and Montsoreau (see Figure 1 for the locations). Turquant is a thriving example of the Loire Valley heritage being successfully opened up to the public. Turquant, like other towns on the banks of the Loire, was once a small village where coopers, sailors, millers, and winemakers lived but development has stalled since the end of the 19th century. Turquant is a combination of several small villages along the hills, which makes it relatively difficult for the community to gather. In addition, unlike neighbouring towns, Turquant is located relatively far from the Loire Valley. It can only overlook the river from the hills, but cannot use the water itself as a lever for development. In 1995, Turquant underwent a historic change in its tourism development policy due to the election of a new panel of elected officials. The municipality developed a local strategy that attempted to convert village resources into tourism assets. Many projects were developed under this strategy, and have contributed to improve the vitality and attractiveness of village. As an example, the 15th-century church, which was threatened with destruction at the time, became a central point for the community while also driving forward the beautification and revival of many man-made caves. Today, thanks to the funding from private companies the church and its stained-glass windows have been restored and it is known as the "Welcoming Church in Anjou". This project has been led by the Tourism Commission in the Maine-et-Loire Department and aims to open and revitalise the local religious heritage. In addition, there are still 160 hectares of vineyards and 13 wineries in operation.

Turquant is also one of the largest mushroom producing areas supplying Paris. However, due to competition in the mushroom market, production is currently experiencing a downward trend which has forced Turquant to find alternative economic activities. For example, troglodyte caves, where shiitake mushrooms used to be grown, are being used for alternative activities. These troglodyte caves certainly represent the villages' main assets and are part of the region's unique character. Turquant was aware of this and therefore decided early on to create a development strategy based on these abandoned underground structures. For instance, the caves were adapted and reused as creative spaces such as for handicraft exhibitions and restaurants so as to transform the village into an emerging tourist attraction (see Figure 9). The main reason that the Turquant community supports tourism development is that, compared to local communities in relatively new tourist destinations, the village became a tourist destination before the WHS status was granted, so it didn't encounter any major problems in adapting to the impact of tourism (Horn \& 
Simmons, 2002; Jimura 2015, 2016b). Moreover, the majority of attractions are outside the village so the locals are not massively affected by the impact of tourism.

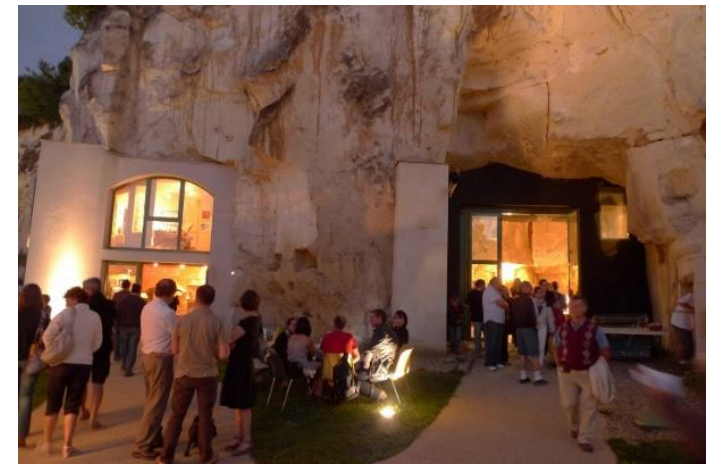

Figure 9. Turquant - adaptive reuse of the troglodyte caves as a strategy for tourism development. Source: Author's own photo (2019)

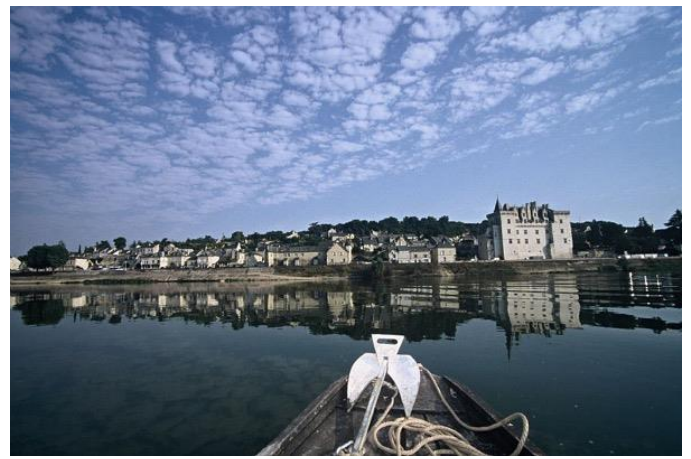

Figure 10. Montsoreau - a panoramic view of the scenic and heritage attractions in the town. Source: Author's own photo (2019)

If the Turquant example is a positive case in the Loire Valley, then the neighbouring village of Montsoreau can be said to be a negative one. Like Turquant, Montsoreau is located in the heart of the Loire Valley. At the end of the 15th century Montsoreau experienced a period of prosperity and development, becoming a site for the transportation of grain, fruits, construction materials, leather, fabrics and other commodities. However, at the beginning of the 20th century with the decrease in sailing on the Loire, the number of residents was still in decline going from more than 10,000 in the 1920 s to just 502 in 2005 . But Montsoreau has many scenic and heritage attractions, including castles, wineries and caves used as houses (see Figure 10). Agriculture and tourism are the main economic sources of revenue in Montsoreau. The former includes vineyards, mushrooms and orchards, while other businesses rely heavily on the village's tourism activities. Montsoreau Castle is the village's main tourist attraction. It was listed as a historical monument in 1862 and is well known thanks to Alexandre Dumas's masterpiece. But the castle is just one of the local heritage sites and the town still has around 10 listed monuments. However, Montsoreau's tourism development faces many challenges.

The village is located between the Loire River and the valley-sides where the hills used to be quarried and mined as the rocks are very soft and easy to break. In addition, the rising water levels of the Loire in winter also put the village at risk of flooding. In terms of human factors, although tourism practitioners hope to vigorously expand the tourism industry, another group of visitors who originally visited Montsoreau as tourists have settled in the town and have in turn become opponents of tourism development. For these people, tourism is synonymous of a disturbed daily life including the lack of parking spaces, pedestrian safety issues, the noise made by tourists, etc. This point reflects the argument of Leask \& Fyall (2006) that if WHS or a tourism destination with WHS mainly focuses on the economic interests of the tourism industry, it may cause negative socio-cultural and/or environmental impacts for the local community. Jimura (2019) believes that the arrival of many tourists and their misconduct may undermine the quality of cultural and natural WHS. Sharpley and Sharpley (1997) also point out that an increase in the scale and level of tourism development usually leads to greater local aversion to tourism. The speed and scale 
of tourism development after WHS registration may be too rapid and too great for local communities to cope with. Another possible objection is that tourism in the Loire Valley is highly seasonal. If there are no tourist activities all throughout the entire year then the local community may not be very optimistic about tourism because it cannot provide them with a constant source of income and stable employment (Jimura, 2011).

On the whole, the local community's position on tourism development can be considered from the perspective of social exchange theory. If the local community believes that the benefits provided by tourism exceed the costs it entails then they will be more supportive of the tourism development (Wang \& Pfister, 2008). Therefore, WHS managers need to find and achieve a good balance between the needs of locals and visitors, since the concerns and priorities of these two groups are often different. WHS managers must determine the ways to reconcile their different aspirations and benefits. However, if WHS becomes too popular among visitors then the managers need to cope with a large number of visitors with different interests and backgrounds. In such a case, this task will become even more demanding.

\section{CONCLUSION}

WHS status is granted by UNESCO, which is a recognition of authenticity and quality and an important source of support for tourism development. As a WHS cultural landscape, the Loire Valley has an environmental background with both cultural and natural values. More importantly, because these often cross provincial and national boundaries, managers are faced with specific challenges. This article focuses on three aspects: tourism governance and marketing, attraction development and activation, as well as considering community and tourism development. First, a territory which crosses administrative boundaries is a major challenge for WHS both in terms of governance and marketing. This is specially true in a large cultural landscape like the Loire Valley where more cross-regional coordination and the development of a complete marketing strategy are needed to stand out from other WHSs and develop their own vision (Jimura, 2019). In addition, linear landscape and heritage routes are considered as special types of cultural landscape, and they have their own management requirements (Rössler, 1994). These routes have been used by the tourism sector, and are more difficult to manage carefully and effectively (McKercher \& du Cros, 2002).

Tourism development in the Loire Valley has some issues, such as short tourist stays, slow growth in tourists number, uneven visiting numbers between castles, and the blurred role of WHS status in the destination's image. Tourism development in the Loire Valley is far from perfectly homogeneous. Significant asymmetries characterize the Loire tourist area, especially with regard to visitor numbers at its castles. Although tourists are mainly concentrated around specific attractions, the limited visitor numbers do not pose a threat to the preservation of the heritage. However, this may lead to an imbalance in the development of the tourist territory, and over-saturate the reception facilities of popular attractions. Basically, with the two brands - Loire Valley and Loire by Bike - some of these challenges to tourism development have been overcome. The former brand emphasises that the meaning of the Loire Valley as a WHS is more extensive than the mere architectural castle heritage. The identity of the river includes aspects such as castles, gardens, nature, 
food, wine, and water leisure activities. It tries to use the entire valley area as a territory to promote the charm of heritage and natural scenery in order to solve the problem of tourists' short stays and the concentration of tourists around just a few well-known attractions.

On the other hand, it has always been difficult for tourists to get close to the Loire Valley, and in the past, there were no activities allowing tourists to approach the river. Loire by Bike provides diverse opportunities to explore flagship attractions, local heritage, and natural scenery in a safe environment. It also builds a connection with the river and strengthens the river valley's identity, both at a geographic level (from Sully to Chalonnes) and a thematic level (heritance, culture and nature). Taking Loire by Bike as its flagship brand will encourage tourists to extend their stay, experience local cultural assets better, and solve the problem of excessive concentrations of tourists at just a few attractions. In addition, the activation of heritage and the organisation of festivals can also help to enhance the competitiveness of heritage sites. This is especially valuable for serious heritage tourists who seek not only visual satisfaction but also intellectual satisfaction from the integrity and authenticity of the place visited (Ryan \& Silvanto, 2014). On the whole, in addition to castles, the Loire needs to highlight its precious assets such as natural landscapes, food and wine, and to enhance the diversity and uniqueness of its tourism supply and attract tourists to visit again.

Lazzarotti \& Violier (2007) and Lazzarotti (2000) believe that using heritage as a lever to promote local development is an important aspect of the relationship between tourism and heritage. However, this view contradicts the arguments for protecting the heritage, restricting tourism mobility, and keeping the heritage open to local residents. As a result, while some actors try to increase the number of tourist activities, another group also imposes restrictions to control the number of tourists and access to the heritage (Morice \& Violier, 2009). This article uses two cases to illustrate the contradiction between the openness and closure of the Loire Valley. Turquant is more supportive of tourism development than Montsoreau. The main reasons include its earlier development of tourism, which began before the WHS name was awarded. In addition, tourism is also an important industry to allow local residents to earn a living. Finally, most of the currently developed tourist attractions are located outside the village, which does not directly affect the quality of life for residents. However, Montsoreau is particularly sensitive to disturbances in quality of life due to the development of tourism because of its narrow terrain. The main residents of Montsoreau are also retirees who emigrated from outside and value highly their quality of life.

Finally, although this article attempts to explore the challenges and development strategies of the Loire Valley as a WHS cultural landscape in the development of tourism, there are still some research limitations which provide pointers for future investigation. First of all, the relevant organisations in the Loire Valley seldom conduct surveys and research looking at tourism development or the WHS status. The survey data that this article relies on were collected ten years ago and cannot provide a comprehensive and up-to-date overview of the latest tourism developments in this territory. In the future, it will be necessary to conduct surveys with tourists and residents to understand the visitors' images, motivations and behaviours, as well as residents' opinions on tourism development. Second, this article identifies Loire by Bike and Loire Valley as the flagship brands for tourism development, 
but evidence of their effectiveness and impact is still lacking and therefore requires practical research and investigation which could be included in a future tourist survey. Third, due to the availability of information, this article only selects three aspects for analysis. In the future, people may consider exploring other issues related to tourism development in WHS.

\section{REFERENCES}

Amélie-Emmanuelle, M. (2007). Les territoires du tourisme en ville: La pratique des acteurs du tourisme dans les villes d'Amboise, de Blois et de Tours. Doctoral dissertation, Angers: University of Angers.

Andereck, K. L. \& Vogt, C.A. (2000). The relationship between residents' attitudes toward tourism and tourism development options. Journal of Travel Research, 39(1), 27-36.

Buckley, R. (2018). Tourism and natural World Heritage: A complicated relationship. Journal of Travel Research, 57(5), 563-578.

Canale, R.R., De Simone, E., Di Maio, A., \& Parenti, B. (2019). UNESCO World Heritage sites and tourism attractiveness: The case of Italian provinces. Land Use Policy, 85, 114-120.

Carter, L., Jolliffe, L. \& Baum, T. (2000). Tourism and world heritage sites. In: Robinson, M., Evans, N., Long, P., Sharpley, R. \& Swarbrooke, J. (eds.), Tourism and Heritage Relationships: Global, National and Local Perspectives. Gateshead, UK: Athenaneum press, pp. 63-75.

DGE (2019). Mémento du Tourisme, 2018 ed. Paris : Direction générale des entreprises (DGE).

Duhamel, P. \& Knafou, R. (2007). Le tourisme dans la centralité parisienne. In : Saint-Julien, T. \& Le Goix, R. La métropole parisienne. Centralités, inégalités, proximités. Paris: Belin, pp.39-64.

Evans, N. (2015). Strategic Management for Tourism, Hospitality and Events, $2^{\text {nd }}$ ed. Oxford: Butterworth Heinemann.

Gravari-Barbas, M., Bourdeau, L. \& Robinson, M. (2015) World heritage and tourism: from opposition to co-production. In: Bourdeau, L., Gravari-Barbas, M. \& Robinson, M. (eds.) World Heritage, Tourism and Identity: Inscription and Co-production. Farnham: Ashgate, pp.1-24.

Hall, C. M. \& McArthur, S. (1998). Integrated Heritage Management. London: The Stationery Office.

Hall, C. M. \& Piggin, R. (2002). Tourism business knowledge of World Heritage sites: A New Zealand case study. International Journal of Tourism Research, 4(5), 401-411.

Horn, C. \& Simmons, D. (2002). Community adaptation to tourism: comparisons between Rotorua and Kaikoura, New Zealand. Tourism Management, 23(2), 133-143. 
Hall, C. M. \& Piggin, R. (2003) World Heritage Sites: managing the brand. In: Fyall, B., Garrod, B. \& Leask, A. (eds.), Managing Visitor Attractions: New Directions. Oxford: Butterworth-Heinemann, pp. 203-219.

Jimura, T. (2011). The impact of world heritage site designation on local communities - a case study of Ogimachi, Shirakawa-mura, Japan. Tourism Management, 32(2), 288296.

Jimura, T. (2015). The relationship between world heritage designation and local identity. In: Bourdeau, L., Gravari-Barbas, M. \& Robinson, M. (eds.), World Heritage, Tourism and Identity: Inscription and Co-production. Farnham: Ashgate, pp. 81-91.

Jimura, T. (2016). World heritage site management: a case study of sacred sites and pilgrimage routes in the Kii mountain range, Japan. Journal of Heritage Tourism, 11(4), 382-394.

Jimura, T. (2019). World Heritage Sites: Tourism, Local Communities and Conservation Activities. London: CABI.

Johnson, J. D., Snepenger, D. J. \& Akis, S. (1994). Residents' perceptions of tourism development. Annals of Tourism Research, 21(3), 629-642.

Kuvan, Y. \& Akan, P. (2005). Residents' attitudes toward general and forest-related impacts of tourism: the case of Belek, Antalya. Tourism Management, 26(5), 691-706.

Lazzarotti, O. (2000). Patrimoine et tourisme, un couple de la mondialisation, Mappemonde, 1, 12-16.

Lazzarotti, O. \& Violier, P. (2007). Tourisme et Patrimoine : Un moment du Monde. Angers: University of Angers

Leask, A. \& Fyall, A. (2006). Managing World Heritage Sites. London: Routledge.

McKercher, B. \& du Cros, H. (2002). Cultural Tourism: The Partnership between Tourism and Cultural Heritage Management. London: Routledge.

McKercher, B., Ho, P. S., Cros, H. D. \& So-Ming, B. C. (2002). Activities-based segmentation of the cultural tourism market. Journal of Travel \& Tourism Marketing, 12(1), 23-46.

Meskell, L. (2013). UNESCO's World Heritage Convention at 40. Current Anthropology, 54, 483-94.

Morice, J. R. \& Violier, P. (2009). Ouverture et fermeture des lieux: l'exemple de la vallée de la Loire, In: Giraud-Labalte, C., Morice, J. R. \& Violier, P. (eds.), Le patrimoine est-il fréquentable? Angers: University of Angers, pp.89-100.

Morice, J. R. \& Chevrel, R. (2010). Étude des comportements des visiteurs des grands sites du Val de Loire. Survey report commissioned by Mission Val de Loire - World Heritage. France: University of Angers and Public \& Culture.

Morice, J. R. (2015). La Loire à Vélo. 303: Arts, Recherches et Créations, 136, 34-41. 
Morice, J. R. (2019). L'infusion socio-spatiale du tourisme: Le cas de la France. Doctoral Qualification to Direct of Research in Geography, Volume 2, Angers: University of Angers.

Pedersen, A., Bushell, R. \& Eagles, P. (2007). The World Heritage tourism programme: Lessons learned." In Bushell, R. \& Eagles, P. (eds.) Tourism and Protected Areas: Benefits beyond Boundaries, Wallingford: CABI, pp.115-28.

Pocock, D. (1997). Some reflections on World Heritage. Area, 29(3); New York: New York University Press.

Rasoolimanesh, S.M., Roldán, J.L., Jaafar, M., \& Ramayah, T. (2017). Factors influencing residents' perceptions toward tourism development: Differences across rural and urban world heritage sites. Journal of Travel Research, 56(6), 760-775.

Ribaudo, G., \& Figini, P. (2017). The puzzle of tourism demand at destinations hosting UNESCO World Heritage Sites: An analysis of tourism flows for Italy. Journal of Travel Research, 56(4), 521-542.

Robinson, R., Wertheim, M. \& Senior, G. (1994). Selling the heritage product. In Harrison, R. (ed.) Manual of Heritage Management. Oxford: Butterworth-Heinemann, pp. 381-399.

Rössler, M. (1994). Cultural landscapes, itineraries and canals for the World Heritage list. In ICOMOS and Ministry of Culture, Spain (eds.) Routes as Part of our Cultural Heritage. Madrid: Meeting of Experts, ICOMOS and Ministry of Culture, pp. 59-70.

Rössler, M. (2000). World Heritage Cultural landscapes. The George Wright Forum, 17(1), $27-34$.

Ryan, J. \& Silvanto, S. (2009). The World Heritage List: The making and management of a brand. Place Branding and Public Diplomacy, 5(4), 290-300.

Ryan, J. \& Silvanto, S. (2014). A study of the key strategic drivers of the use of the World Heritage site designation as a destination brand. Journal of Travel \& Tourism Marketing, 31(3), 327-343.

Santa-Cruz, F. G., \& López-Guzmán, T. (2017). Culture, tourism and world heritage sites. Tourism Management Perspectives, 24, 111-116.

Shackley, M. (ed.)(1998). Visitor Management. Case Studies from World Heritage Sites. Oxford, UK: Butterworth-Heinemann.

Sharpley, R. \& Sharpley, J. (1997). Rural Tourism: An Introduction. London: International Thomson Business Press,

Sirisrisak, T. \& Akagawa, N. (2007). Cultural landscape in the world heritage list: Understanding on the gap and categorization. City \& Time, 2(3), 11-20. 
Smith, M. (2002). A critical evaluation of the global accolade: the significance of World Heritage Site status for maritime Greenwich. International Journal of Heritage Studies, 8(2), 137-151.

Stocks, J. (1996) Heritage and tourism in the Irish Republic - towards a giant theme park. In: Robinson, M., Evans, N. \& Callaghan, P. (eds.) Tourism and Culture: Image, Identity and Marketing, Sunderland: The Centre for Travel and Tourism/British Education Publishers, pp. 251-260.

Thorsell, J. \& Sigaty, T. (2001). Human use in world heritage natural sites: A global inventory. Tourism Recreation Research, 26(1), 85-101.

Trease, G. (1967). The Grand Tour. London: Heinemann.

UNESCO (2013). Convention Operational Guidelines - World Heritage Convention. Available at: http://whc.unesco.org/pg.cfm?cid=57 (accessed July 2019).

UNESCO (2018). World Heritage List. Available at: whc.unesco.org. (accessed July 2019).

UNESCO (2020). The Loire Valley between Sully-sur-Loire and Chalonnes. Available at: https://whc.unesco.org/en/list/933. (accessed July 2019).

Violier, P. (2003). Les acteurs du tourisme. In: Stock, M. (ed.), Le tourisme : Acteurs, lieux et enjeux. Paris: Belin, pp.167-208.

Wang, Y. \& Pfister, R. E. (2008). Residents' attitudes toward tourism and perceived personal benefits in a rural community. Journal of Travel Research, 47(1), 84-93. 